\title{
Developing Business Writing Skills and Reducing Writing Anxiety of EFL Learners through Wikis
}

\author{
Mohamed Ali Mohamed Kassem ${ }^{1}$ \\ ${ }^{1}$ The New Valley Faculty of Education, Assiut University, Al Kharja, Egypt \\ Correspondence: Mohamed Ali Mohamed Kassem, The New Valley Faculty of Education, Assiut University, Al \\ Kharja, Postal code 72511, Egypt. Tel: 002-01111-996-228. E-mail: m_kassem1@yahoo.com
}

Received: January 3, 2017 Accepted: February 15, 2017 Online Published: February 19, 2017

doi: 10.5539/elt.v10n3p151 URL: http://dx.doi.org/10.5539/elt.v10n3p151

\begin{abstract}
The present study aimed at investigating the effect of using wikis on developing business writing skills and reducing writing anxiety of Business Administration students at Prince Sattam bin Abdul Aziz University, KSA. Sixty students, who were randomly chosen and divided into two equivalent groups: control and experimental, participated in the study. Two main tools were devised to collect data: Test of Business Writing Skills (TBWS) and Writing Anxiety Inventory (WAI). The experiment was conducted during the second semester of the academic year 2015-2016. A t-test was utilized to calculate the differences between the mean scores of the two groups in pre- and post-intervention. The findings of the study showed statistically significant differences between the mean scores of the experimental group and the control group on the post-TBWS in favor of the experimental group. In addition, the writing anxiety level of the experimental group, after the intervention, was significantly less than the control group. These findings revealed the positive effects of wikis on developing business writing skills and reducing writing anxiety of EFL learners. It is recommended that sufficient training should be provided to instructors on how to integrate wikis in business writing instruction. Pedagogical implications and suggestions for further research are presented.
\end{abstract}

Keywords: business writing, wikis, writing anxiety

\section{Introduction}

The significance of writing is stressed by many researchers (Li, 2012; Choi, 2013; Olanezhad, 2015) who assured the crucial role that writing has played in the history of mankind. Writing provides people with a means to communicate their feelings, achievements, dreams, and opinions. Writing bridges the gap and connects people from different backgrounds and across borders. Writing is of paramount importance for EFL learners. It is a survival skill as students are obliged to use it as a medium for learning other courses, to prepare home assignments and projects and, eventually, to communicate with their instructors. According to Condon and Kelly-Riley (2004), writing is a prerequisite for success in all academic fields and in workplace as well. However, writing is the most challenging language skill to master for both first and foreign language students (Umar \& Rathakrishnan, 2012). Writing is an extremely complex process that requires a control over a wide variety of tasks ranging from letter formation and spelling to effective use of rhetorical patterns. The difficulty of writing is increased when students are required to write business documents such as letters, memos, proposals and reports. Actually, mastering business writing skills contributes to the success of business and to achieve customer's satisfaction. Poorly written documents may cause waste of time, money and efforts (Killeen, 2013).

Business writing is an important form of written communication. Currently, it is utilized in all firms for internal and external correspondence. Using this type of communication is recommended as it saves a record of the messages to be checked later for improvement and analysis. In addition, it provides recipients with enough time to read the messages carefully. Finally, it is more appropriate for complex messages that include much details and statistics (Tymson, Lazar, \& Lazar, 2008).

It has been observed that producing business documents drive many students to experience high level of anxiety. Wilt, Oehlberg and Revelle (2011: 987) define language anxiety as "a personality trait and an emotional and behavioral state" that affects one's success in acquiring and learning language. There are two types of anxiety: facilitative and debilitative. The first type expresses a reasonable and acceptable level of anxiety that may motivate students to learn and exert more efforts. The other type of anxiety, the main concern of the present 
study, is the debilitative anxiety which has negative effects on the students' ability to carry out the writing tasks. In this regard, several studies have demonstrated that learners with high level of writing anxiety are poor writers who consider writing as a challenging process that goes far beyond their capabilities (Atay \& Kurt, 2006; Huang, 2009; Karakaya \& Ulper; 2011; Huwari, 2016).

Studies which have investigated how the learners' performance in writing correspond with writing anxiety show the following results: (1) learners with high level of anxiety get low scores on standardized tests of writing (Wen-Shuenn, 2006), (2) EFL learners' writing quality is negatively affected by writing anxiety (Atay \& Kurt, 2006; Kara, 2013; Olanezhad, 2015), and (3) writing in the target language involves a high level of anxiety as writing is a skill that expects individuals to work individually (Tsui, 1996). In turn, a large number of EFL learners consider writing as a process that provoks much anxiety. This motivates many researchers (Jahin, 2007 \& Bobanovic, 2016) to employ different techniques to assist their students in overcoming their writing anxiety such as working in groups and establishing a sense of community in the class. Thus, creating a non-threatening environment in English writing classes is essential to reduce students' English writing anxiety.

Modern technology seems to carry the real potentiality to create such an environment that enables students to lower or even to get rid of their writing anxiety. Wiki is one of the Web 2.0 technologies that has grasped the attention of researchers and teachers in the last decade with its multifarious applications: it provides teachers with an easily accessible medium of online instruction; it promotes cooperation and active interaction among students; it provides rich opportunities for sharing information; finally, it facilitates the writing process (Boulos, Maramba, \& Wheeler, 2006). In the Hawaiian language, the word 'wiki' means 'quick'. It was borrowed to indicate the quickness and easiness of establishing a website that permits online group work (Lamb \& Johnson, 2007). Ward Cunningham was the first scholar to create and use wiki, in 1995, as a composition system that allowed collaboration and discussion among its users. It was described as "a freely expandable collection of interlinked web pages, a hypertext system for storing and modifying information-a database, where each page was easily edited by any user with a forms-capable Web browser client" (Cunningham \& Leuf, 2001). The last decade witnessed an increasing tendency towards the integration of new technology especially wikis in education. It was first used in computer sciences and quickly shifted to social sciences (Gabrilovich \& Markovitch, 2006).

Several studies have referred to the advantages of using wikis in instruction. Ebersbach, Glaserand and Heigl (2006) claim that the process of creating and editing wikis is simple and explicit as it does not require much experience and technical knowledge. Being connected to the internet is all what teachers and students need to access and edit wikis. In addition, wikis enable students to easily share their postings with their colleagues and exchange feedback in a supportive environment. Moreover, wikis provide its users with a record of all changes and modifications that have taken place over time. This enables both the students and the teachers to track their progress and to evaluate the writing process as a whole. Woods and Thoeny (2011) confirmed that wikis support collaboration among students. They act like authors and the final product reflects the contributions of every single member in the group. Additionally, wikis support learner's autonomy as students plan their contribution, monitor their progress, take decision and, eventually, show a tendency towards self learning in general. Nowadays, educators and academicians use wiki technology in all educational stages and academic programs.

Previous Studies that investigated the direct effect of foreign / second web-based language learning on learners' writing and anxiety are still not numerous. They reveal that web-based writing improve learners' attitude and decrease their writing apprehension (Pae, 2007; Bobanović, 2016). A few others have demonstrated that web-based writing instruction has a positive impact on the quality and quantity of learners' writing compared to the effects of the traditional methods (Lamb, 2004 \& Langdon, 2005). There are also studies which have proved that web-based language writing has no significant effect on learners' performance and on reducing their writing apprehension (Biesenbach-Lucas, Meloni, \&Weasenforth, 2001). In the light of the facts mentioned above and considering the importance of business writing and the benefits that could be gained with the implementation of wikis in writing classes, the current study attempts to investigate the impact of using wikis on developing business writing skills and reducing writing anxiety of Business Administration students.

\subsection{Context of the Problem}

Students pursuing the Business Writing Course, at College of Business Administration, Prince Sattam bin Abdul Aziz University, show serious weaknesses in writing in general and in business writing in particular. Their written products are of poor quality. They seem not to have acquired the skills and techniques which would enable them to write well. In addition, many students display a high level of writing anxiety that hinders them from processing the writing tasks on several occasions. This inspired the researcher to investigate the status-quo 
of business writing instruction to find out the difficulties that many students encounter in business writing and to, eventually, suggest a remedy.

These observations are consistent with the views of several scholars who regard writing as the most challenging skill for Saudi students in all educational stages (Alshumaimeri, 2011). They opine that little attention is given for developing the students' writing skills especially in the pre-university stage. Writing instructors emphasize the importance of using correct forms and avoiding errors of conventions. Thus, students tend to memorize some passages written by their teachers without having a real chance to reflect their ideas and personalities in writing (Jahin, 2007; Jahin \& Idrees, 2010; Aljafen, 2013).

To ascertain how serious the problem of students' writing is, semi-structured interviews were conducted with writing instructors in which many questions regarding students' business writing and writing anxiety were addressed. Results of these interviews supported the researcher's initial observations. Additionally, a pilot study was carried out to identify the actual level of business writing skills and writing anxiety of the students. Twenty students participated in this pilot study. They were provided with four writing tasks to complete (a business report, an e-mail, a memo, and a business proposal). Analyzing students' writings revealed remarkable weaknesses in such skills. In addition, their responses to the writing anxiety inventory revealed that a large number of students (71\%) suffered from a high level of writing anxiety.

\subsection{Statement of the Problem}

Second year students at College of Business Administration, Prince Sattam bin Abdul Aziz University, Saudi Arabia, suffer from poor business writing skills and a high level of writing anxiety. Using Wikis is, therefore, suggested to develop their business writing and to reduce their writing anxiety.

\subsection{Questions of the Study}

The questions formulated for the present study were:

1- What is the effect of using wikis on developing business writing skills of Business Administration students?

2- What is the effect of using wikis on reducing writing anxiety of Business Administration students?

\subsection{Hypotheses of the Study}

Two hypotheses were formulated in the present study:

1- There would be statistically significant differences between the mean scores of the experimental group and the control group on the post-test of business writing skills in favor of the experimental group.

2- There would be statistically significant differences between the mean scores of the experimental group and the control group on the post-application of writing anxiety inventory in favor of the experimental group.

\subsection{Delimitations of the Study}

The current study was delimited to four business writing skills:

- E-mail writing

- Report writing

- Proposal writing

- Memo writing

\subsection{Significance of the Study}

The significance of the present study can be stated as follows:

1- The study attempted to introduce wiki, one of the Web 2.0 tools, that would help in developing the students' business writing skills. This, in turn, would pave the way for future studies to be conducted using this technology in developing other language skills.

2- The study attempted to address an important aspect of the writing process that deals with the students' writing anxiety. This will help EFL writing instructors in creating a deeper understanding of writing anxiety that negatively affects their students' writing performance.

3- The outcomes of the present study will hopefully draw the attention of curriculum planners and designers to the benefits of integrating Web 2.0 tools into writing classes.

\section{Review of Literature}

2.1 Using Wikis in Writing Instruction 
Xiao and Lucking (2008) carried out a study to examine how a wiki-based peer evaluation technique influenced the academic writing skills of EFL university students. It was confirmed that the experimental group significantly developed their academic writing compared to the control group. Similarly, another study found that wikis helped grade seven students in Hong Kong in developing the quality and the quantity of their authentic writing (Coniam \& Mak, 2008). Moreover, the students' writing coherence was improved and their motivation was increased. In the same year, a study was conducted to explore the potentiality of incorporating wikis in writing instruction (Lundin, 2008). Lundin hypothesized that wikis can change the current pedagogical assumptions about writing instruction. Her findings revealed that wikis had a positive effect on first year composition classes as students' scores were improved after the experiment. Wichadee (2010) investigated the effect of using wikis on developing summary writing abilities of EFL students at Bangkok University and found out: (1) a positive effect of wikis on the participants' summary writing abilities as shown in their post-test of writing, and (2) a positive effect on the students' attitude towards learning in general. Similarly, Ahmadi and Marandi (2014) conducted an empirical study to examine the impact of wikis on university learners' writing skills in Iran. They found out that the experimental group outperformed the control group in writing performance. Accordingly, the study confirmed the positive impact of wikis on developing students' writing skills.

Previous studies have investigated the teachers' role in a wiki-based writing instruction. According to Weimer (2002), the role of the teacher has witnessed a radical change as a result of a growing tendency to incorporate technology in teaching practices. The teacher is no longer the sole source of information and feedback. He has assumed the role of a facilitator who facilitates the learning process, helps students to launch their critical and creative abilities and creates a supportive learning environment. West and West (2009) proposed a few guidelines for such instructors who would like to incorporate wikis in their teaching practices, namely (1) develop your skills in using modern technology especially Web 2.0 technology and be up-to-date with new innovations and recent applications by other teachers, (2) be familiar with the potentialities of the wikis you are creating, (3) create wikis that allow your students to insert texts, images, hyperlinks and charts, (4) provide students with all the necessary information about how to log in, how to correct errors, and how to post. So, an orientation should be given prior to the actual use of wikis. Such information may be available in the wikis too, and finally (5) guide students throughout the learning process. Meanwhile, students should grasp the opportunity to lead the learning process.

The discussion of the teacher's new roles is extended by Hussein (2010) and Uzunboylu, Bicen, and Cavus (2011) who mentioned some more assigned roles like: (1) clarifying the objectives and critical concepts, (2) motivating students and providing them with constructive feedback, (3) involving all students in collaborative discussion especially poor learners, (4) encouraging peer editing and guiding the discussion, (5) helping students to be open-minded and avoiding bias, and (6) urging students to utilize online resources utmost to support their learning process.

Prior studies (West \& West, 2009; Li, 2012; Huwari, 2016) have referred to a few basic guidelines to direct teachers in the process of creating and using wikis in instruction. First, teachers must identify themselves with the objectives of the wiki project in order to justify and offer a rationale for using an online collaborative tool. They must also accept wikis as the most appropriate medium to foster student's learning, rather than seeing it as a mere new technology. Moreover, an understanding of the objectives will also help teachers to structure their wikis and specify the learning domain and learning outcomes in their teaching, which they are required to articulate as direct or indirect. Second, teachers initiate the designing process by selecting an appropriate wiki from the available templates and automated programs. Teachers need to follow instructions and move from one step to another till the wiki is established. There is no one single template for wikis. Some wikis have a single page that is linked to a series of hyperlinked pages organized according to learners' proficiency and needs. Third, students are oriented to the various functions and features of the wiki before inviting them to initiate the process of learning from and contributing to the content of the wiki. In this stage, students share the responsibility of monitoring their own progress, providing peer feedback and working collaboratively to carry out tasks within the given deadline. Fourth, students are responsible for distributing roles and tasks among themselves equally. Teachers should make sure that every student understands what he is expected to do. Finally, studnts' contribution and progress should be monitored and assessed by teachers.

\subsection{Business Writing}

Bohns (2015) referred to four kinds of communication pertinent to business writing: results-oriented communication, informational communication, persuasive communication and negative communication. Each type has a specific goal and purpose. For instance, the results-oriented communication seeks to drive the reader to take a certain act or to follow specific instructions; informational communication aims at providing the readers 
with information without achieving a specific goal; persuasive communication seeks to convince the reader of the benefits of a certain product or service while negative communication presents a negative subject such as a layoff or a salary reduction. This is consistent with Graham (2008) who has further reiterated this division and emphasized on the use of the right tone and content. Thus, it can be concluded that business writing is not limited to exchanging information only and its purpose varies from one situation to another.

Business writing has unique features that distinguish it from other types of writing. Clarity is an essential feature as misinterpretation may cause severe damages. Thus, writers should be careful in articulating concise ideas, choosing accurate words and structuring complete sentences (Lundin, 2008). Using a formal style and right conventions characterizes effective business writing and reflects professional image of the company. Nikitina (2012) stressed the importance of completeness maintaining that having incomplete information may destroy the communication process. Additionally, a business document should provide the readers with sufficient knowledge of what, when and how. Killeen (2013) stated that identifying the purpose and the audience is a prerequisite for successful business writing. Identifying the purpose will guide you in the process of structuring the business written documents and in selecting the appropriate tone and style. The written document may aim to inform, to invite, to request, to persuade or to suggest. Identifying the audience- knowing the needs, mentality and features of the expected readers- will help writers in crafting written documents that positively affect the readers.

In business writing several mistakes may cause breakdown in communication. Dwyer (2005) stressed the importance of avoiding the following mistakes: using inappropriate words and tone, sending incomplete messages, inappropriate layout and poor presentation of the content, providing inadequate feedback and, finally, ignoring cultural and linguistic barriers. In this regard, the present study sought to use several techniques to enable students to avoide such mistakes.

\subsection{Writing Anxiety}

Over the last two decades, many studies have been carried out to identify the possible causes of writing anxiety and to find out some techniques that could pave the way for establishing a free-anxiety learning environment. Abdel Latif (2007) believes that the writing instructors' overemphasis of writing conventions in the expense of content and ideas causes anxiety. Fritzsche, Youn, and Hickson (2003) claimed that the adoption of the product approach in writing instruction could be the cause of students' writing anxiety. Instructors' focus on theoretical concepts, the neglect of real practice of writing, students' insufficient knowledge of the language and their negative feelings towards writing, instructors' negative responses and over criticism of students' early writing attempts negatively affect their writing performance and increase their level of writing anxiety (Stapa \& Abdul Majid, 2009). Finally, Olanezhad (2015) showed that evaluation of student's individual writings and the high possibilities to lose face increase the students' writing anxiety.

On the other hand, much research has been done to address the problem of writing anxiety. In this regard, the scholarly evidence suggests a few techniques to decrease the students' writing anxiety: for instance, students should be provided with writing assignments that are not graded to help them in getting rid of their fear of a negative evaluation (Clark, 2005): peer feedback and self-correction must be speculated as an alternative of teacher's feedback: the approach of writing as a process should be adopted: students' voices should be appreciated and individual differences should be respected (Rankin-Brown, 2006): students are required to overcome their anxiety and fear of writing through cooperative work: working in groups is recommended to reduce students' anxiety (Kurk \& Atay, 2007) and students should be provided with the evaluation criteria upon which their writings will be evaluated.

Many studies (Hassan, 2001; Atay \& Kurt, 2006; Abdel Latif, 2007; Magno, 2008; Choi, 2013) attempted to investigate different aspects of the relationship between students' performance and writing anxiety. Hassan (2001), for isntance, conducted an empirical study to examine the impact of writing anxiety on the students' writing quality and asserted the negative effect of writing anxiety. In their (2006) study, Atay and Kurt also found the majority of the participants suffering from a high level of writing anxiety despite their long study of writing as prospective teachers of English. Abdel Latif (2007) confirmed the correlational relationship between linguistic knowledge and writing anxiety claiming that students with proficient linguistic knowledge suffer less from writing anxiety. Magno (2008) showed that writing anxiety can be used to predict the level of students' writing proficiency. Finally, the study of Choi (2013) referred to the significant correlation between learners' writing anxiety and their performance in writing.

In conclusion, the previous studies indicated the correlational relationship between students' writing performance and their writing anxiety. However, none of these studies has attempted to identify the possible effect of using wikis on EFL learners' business writing skills. 


\section{Method}

\subsection{Sample of the Study}

Sixty EFL students from second year at College of Business Administration, Prince Sattam bin Abdul Aziz University, Saudi Arabia were chosen randomly to participate in the experiment. They were divided into two equivalent groups, control and experimental, of thirty students each. The groups were equivalent in terms of English language proficiency, age, and computer skills. The Standardized Test for English Proficiency (STEP) issued by the Saudi National Center for Assessment and the International Computer Driving Licence (ICDL) test were used to guarantee the equivalence of the two groups. Moreover, to make sure that the two groups were equivalent in their business writing too, a test of business writing skills was run before the start of the experiment. Results of the test indicated that the control group and the experimental group were equivalent in their business writing skills prior to the intervention.

\subsection{Design of the Study}

A pre-test/post-test experimental and control group design was utilized in the present study. The business writing test and the writing anxiety inventory were administered on both groups before the start of the experiment. The experimental group studied the business writing course using wikis, whereas the control group adopted the traditional method in studying the same material.

\subsection{Instruments}

\subsubsection{Test of Business Writing Skills (TBWS)}

The aim of the test was to measure the business writing skills of second year students at College of Business Administration, Prince Sattam bin Abdul Aziz University, Saudi Arabia. The TBWS comprised four questions. Each question tackled a major business skill and received an equal relative weight of (25\%):

Question 1: Write a memo ordering some office supplies.

Question 2: Write a report presenting your ideas.

Question 3: Write a proposal offering your services.

Question 4: Write an e-mail confirming a meeting.

A 4-point rubric was developed for scoring the test. Four fundamental aspects of quality business writing were measured through this rubric: (1) form, (2) organization, (3) content and (4) Mechanics. Each aspect/criterion had a maximum score of four points; therefore, the maximum score for the test was (16) points. Two experienced raters voulnteerd to participate in scoring each student's paper. The raters independently rated the student's business documents using the scoring rubric designed previously by the researcher. In addition, the researcher provided raters with a set of anchor papers as examples to guide them on the scoring process. To decide content and face validity, the test and the 4-point scoring rubric were submitted to a jury of ten writing experts. All their comments and suggestions were included in the final version of the test. Thus, the test was approved as a valid and appropriate tool for measuring the students' business writing. A test- retest method was used to estimate the reliability of the test. The test was administered on a group of twenty students who represented the target population. They were excluded from the sample of the study. After that, Pearson product moment correlation formula was used to estimate the coefficient of stability, $(\mathrm{r}=.79)$, of the test. This indicates that the test is reliable. In the piloting stage, the optimal test time was calculated. Accordingly, (60) minutes was recommended to be the test time.

\subsubsection{Writing Anxiety Inventory (WAI)}

The Writing Anxiety Inventory was designed to measure the degree of writing anxiety of the students when writing business documents in an EFL context. It comprised (12) statements all of which are answered on a five-point Likert Scale, ranging from 1 (strongly disagree) to 5 (strongly agree). Students with score of $75 \%$ and more were assumed to suffer from a high level of writing anxiety whereas those whose score range from $50 \%$ to $74 \%$ were assumed to have a moderate level of writing anxiety. Students with score of less than $30 \%$ were identified as students with an acceptable level of writing anxiety.

To decide content and face validity, the inventory was submitted to a panel of TEFL experts. After revising the inventory, based on the review of the experts, the final version consisted of (12) items. Thus, it was an approved, validated and appropriate tool for measuring Business Administration students' writing anxiety. The reliability of the WAI was assessed via the test-retest method. It was administered twice to a sample of twenty students who were excluded from the main sample of the study later on. Four weeks separated the two administrations. 
An Alpha Cronbach's correlation coefficient of (.88) was calculated. Moreover, an internal consistency reliability check was computed and it was found that the alpha coefficient for the WAI was (.90).

\subsection{Procedures}

In the first semester of the academic year 2015/2016, the instruments of the study (WAI and TBWS) were piloted with a group of students representing the target population. Based on the results, a few modifications were included in the final version of the instruments. The experiment was carried out during the second semester of the academic year 2015-2016 and lasted for fifteen weeks (3hours a week). Before starting the experiment, the participants were acquainted with the objectives, instruments and procedures of the study. In addition, they were introduced to the rubric of the TBWS to raise their awareness of the criteria upon which their business writing would be evaluated. To prevent any negative impact on students' performance in the test, the WAI was conducted two weeks before the TBWS. The WAI was translated into the mother tongue of the students to avoid any misinterpretations. Then, it was administered to the sample of the study. Before introducing wikis to the experimental group, the TBWS was conducted on both groups. After experimentation, both groups were post-tested.

Before starting the experiment, a wiki was created. For this research, Owiki (http://www.story4u.co.kr) was selected out of the various kinds of wiki engines because it provides useful features that are appropriate for teaching and learning writing in class. It is log-on based and allows its users to control the access rights of reading or writing the content on the wiki. It provides a visual comparison of before and after revising the content. Moreover, it is free of charge and easy to use.

In the first week, participants were oriented to how to use a wiki in business writing. Next, students were divided into groups. Each group had five members. They were required, with the help of the teacher, to construct their own wikis pages to allow them to work cooperatively. Then students were assigned to practice the different business writing formats. Students were requested to submit their writings (postings) in sequence. So, each posting was followed by peer revision and correction. Students were advised to avoid rating the writings as the main objective was to focus on how to improve the quality of their postings. At that time, the teacher was keen to encourage such active interaction among students. Finally, a class discussion was followed and constructive feedback was presented. One of the problems that the students encountered in using wikis was the lack of certain features such as spell-check or auto-correction functions which they were accustomed to use with word-processing programs. Students were advised to check online dictionary from time to time.

\section{Results and Discussion}

\subsection{Testing the First Hypothesis}

The first hypothesis of the study predicted statistically significant differences between the mean scores of the experimental group and the control group on the post-application of TBWS in favor of the experimental group. An independent-samples t-test was conducted to compare the mean scores of the experimental group and the control group on the post application of TBWS. The results, displayed in Table 1, showed statistically significant difference in the scores for the experimental group $(\mathrm{M}=11.9, \mathrm{SD}=1.64)$ and the control group $(\mathrm{M}=7.43, \mathrm{SD}=$ $2.06) ; t(58)=9.27, p=0.01$ in favor of the experimental group. These findings affirmed the first hypothesis and indicated that the superiority of the experimental group over the control group is attributed to the positive impact of using wikis in teaching business writing.

Table 1. Independent-samples t-test results for the differences in the mean scores between the control group and the experimental group on the post application of TBWS

\begin{tabular}{lllllll}
\hline Group & $\mathrm{N}$ & Mean & Std. Deviation & $\mathrm{t}$ & $\mathrm{df}$ & Sig.(2-tailed) \\
\hline Control & 30 & 7.43 & 2.063 & 9.268 & 58 & 0.01 \\
Experimental & 30 & 11.90 & 1.647 & & & \\
\hline
\end{tabular}

The experimental group students' business writing improvement in terms of form, organization, content and mechanics, as presented by their writing scores on each item compared to the students of the control group, is displayed in Table 2. The mean score of each item on the experimental group students' post- test is higher than that of the control group $(\mathrm{M}=3.63>2.07$ for form; $\mathrm{M}=3.10>1.97$ for organization; $\mathrm{M}=2.67>1.73$ for content; $\mathrm{M}=2.53>1.67$ for mechanics). Among the four aspects of business writing, the students improved the most in 
form $(\mathrm{M}$ difference $=1.56)$ whereas the less improvement was in machanics $(\mathrm{M}$ difference $=.86)$. In addition, the results indicated that using wiki led to a significant improvement in all aspects of buiseness writing of the experimental group students.

Table 2. Independent-samples t-test results for the differences in the mean scores between the control group and the experimental group on the post application of TBWS in terms of form, organization, content and mechanics

\begin{tabular}{lllllll}
\hline \multirow{2}{*}{ TBWS } & \multicolumn{7}{l}{ Control Group } & \multicolumn{2}{l}{ Experimental Group } \\
\cline { 2 - 8 } & $M$ & $S D$ & $M$ & $S D$ & $t$ & $p$ \\
\hline Form & 2.07 & 0.52 & 3.63 & 0.72 & 9.67 & $0.01^{*}$ \\
\hline Organization & 1.97 & 0.76 & 3.10 & 0.59 & 6.60 & $0.01^{*}$ \\
\hline Content & 1.73 & 0.64 & 2.67 & 0.48 & 6.39 & $0.01^{*}$ \\
\hline Mechanics & 1.67 & 0.66 & 2.53 & 0.57 & 5.43 & $0.01^{*}$ \\
\hline
\end{tabular}

Note: $* \mathrm{p}<.01$.

\subsection{Testing the Second Hypothesis}

The second hypothesis of the study predicted statistically significant differences between the mean scores of the experimental group and the control group on the post-application of WAI in favor of the experimental group. An independent-samples t-test was conducted to compare the mean scores of the experimental group and the control group on the post application of WAI. The results, displayed in Table 3, showed statistically significant difference in the scores for the experimental group $(\mathrm{M}=29.17, \mathrm{SD}=4.25)$ and the control group $(\mathrm{M}=48.47, \mathrm{SD}$ $=7.59) ; \mathrm{t}(58)=12.15, \mathrm{p}=0.01$ in favor of the experimental group. The results, displayed in Table 3 , indicated that the experimental (wiki) group participants experienced significantly less writing anxiety than the control group participants. The findings affirmed the second hypothesis of the study.

Table 3. Independent-samples t-test results for the differences in the mean scores between the control group and the experimental group in post application of WAI

\begin{tabular}{lllllll}
\hline Group & $\mathrm{N}$ & Mean & Std. Deviation & $\mathrm{t}$ & $\mathrm{df}$ & Sig.(2-tailed) \\
\hline Control & 30 & 48.47 & 7.59 & 12.15 & 58 & 0.01 \\
Experimental & 30 & 29.17 & 4.25 & & & \\
\hline
\end{tabular}

Table 4 presents the means, frequencies and percentages of the control group students' responses to the WAI statements. According to the five-point likert scale, the students who had the highest means $(4,5)$ had a high level of writing anxiety whereas the students who had the lowest means $(1,2)$ had an acceptable level of writing anxiety. A mean of 3.00 literally means that the students were uncertain about their feeling toward the statements; however, this score is considered a moderate feeling of anxiety. The control group students' scores averaged above 3 and 4 for all the statements of the inventory. This means that the students were suffering from a high level of writing anxiety. The results showed a number of thoughtful remarks: the mean of the third statement was $\mathrm{M}=4.56$ which indicated that writing under time limit was a major source of the students' anxiety; the students' responses to the fifth statement, the mean was $M=4.00$, showed that students had negative feelings towards writing and, eventually, evaluation was considered as a source for provoking students' writing anxiety. 
Table 4. Means, frequencies and percentages of the control group students' responses to the WAI statements

\begin{tabular}{|c|c|c|c|c|c|c|c|c|c|c|c|}
\hline \multirow[b]{2}{*}{$\begin{array}{l}\text { Item } \\
\text { No. }\end{array}$} & \multirow[b]{2}{*}{ Statement } & \multirow[b]{2}{*}{$N$} & \multirow[b]{2}{*}{ Min } & \multirow[b]{2}{*}{$\operatorname{Max}$} & \multirow[b]{2}{*}{$M$} & & \multicolumn{5}{|c|}{ Control Group } \\
\hline & & & & & & & 1 & 2 & 3 & 4 & 5 \\
\hline \multirow[t]{2}{*}{1} & \multirow{2}{*}{$\begin{array}{l}\text { I feel nervous when } \\
\text { I write. }\end{array}$} & \multirow[t]{2}{*}{30} & \multirow[t]{2}{*}{1} & \multirow[t]{2}{*}{5} & \multirow[t]{2}{*}{4.33} & Frequency & 0 & 1 & 5 & 7 & 17 \\
\hline & & & & & & Percentage & 0 & 3.3 & 16.7 & 23.3 & 56.7 \\
\hline \multirow[t]{2}{*}{2} & \multirow{2}{*}{$\begin{array}{ll}\text { Evaluating } & \text { my } \\
\text { writings is a real } \\
\text { embracement. }\end{array}$} & \multirow[t]{2}{*}{30} & \multirow[t]{2}{*}{1} & \multirow[t]{2}{*}{5} & \multirow[t]{2}{*}{3.80} & Frequency & 0 & 1 & 10 & 13 & 6 \\
\hline & & & & & & Percentage & 0 & 3.3 & 33.3 & 43.3 & 20.0 \\
\hline \multirow[t]{2}{*}{3} & \multirow{2}{*}{$\begin{array}{l}\text { I feel scared when I } \\
\text { write under time } \\
\text { limitation. }\end{array}$} & \multirow[t]{2}{*}{30} & \multirow[t]{2}{*}{1} & \multirow[t]{2}{*}{5} & \multirow[t]{2}{*}{4.56} & Frequency & 0 & 0 & 2 & 9 & 19 \\
\hline & & & & & & Percentage & 0 & 0 & 6.7 & 30.0 & 63.3 \\
\hline \multirow[t]{2}{*}{4} & \multirow{2}{*}{$\begin{array}{l}\text { I feel that } \\
\text { developing } \\
\text { well-organized } \\
\text { writings is beyond } \\
\text { my capabilities. }\end{array}$} & \multirow[t]{2}{*}{30} & \multirow[t]{2}{*}{1} & \multirow[t]{2}{*}{5} & 3.66 & Frequency & 0 & 2 & 10 & 14 & 4 \\
\hline & & & & & & Percentage & 0 & 6.7 & 33.3 & 46.7 & 13.3 \\
\hline 5 & I predict to do & 30 & 1 & 5 & 4.00 & Frequency & 0 & 1 & 11 & 6 & 12 \\
\hline & $\begin{array}{l}\text { poorly in writing } \\
\text { classes. }\end{array}$ & & & & & Percentage & 0 & 3.3 & 36.7 & 20.0 & 40.0 \\
\hline 6 & I avoid practicing & 30 & 1 & 5 & 4.83 & Frequency & 0 & 0 & 0 & 5 & 25 \\
\hline & $\begin{array}{l}\text { writing outside the } \\
\text { class. }\end{array}$ & & & & & Percentage & 0 & 0 & 0 & 16.7 & 83.3 \\
\hline 7 & Writing is a real & 30 & 1 & 5 & 3.90 & Frequency & 0 & 1 & 10 & 10 & 9 \\
\hline & waste of time. & & & & & Percentage & 0 & 3.3 & 33.3 & 33.3 & 30.0 \\
\hline 8 & I feel that my & 30 & 1 & 5 & 4.00 & Frequency & 0 & 1 & 8 & 12 & 9 \\
\hline & $\begin{array}{l}\text { colleagues' writings } \\
\text { are better than mine. }\end{array}$ & & & & & Percentage & 0 & 3.3 & 26.7 & 40.0 & 30.0 \\
\hline 9 & I do my best to avoid & 30 & 1 & 5 & 3.76 & Frequency & 0 & 2 & 8 & 15 & 5 \\
\hline & written assignments. & & & & & Percentage & 0 & 6.7 & 26.7 & 50.0 & 16.7 \\
\hline 10 & I do not like my & 30 & 1 & 5 & 4.73 & Frequency & 0 & 0 & 2 & 4 & 24 \\
\hline & $\begin{array}{l}\text { colleagues to read } \\
\text { my writings. }\end{array}$ & & & & & Percentage & 0 & 0 & 6.7 & 13.3 & 80.0 \\
\hline 11 & I expect to get low & 30 & 1 & 5 & 3.60 & Frequency & 0 & 3 & 7 & 19 & 1 \\
\hline & $\begin{array}{l}\text { score in writing } \\
\text { assignments. }\end{array}$ & & & & & Percentage & 0 & 10.0 & 23.3 & 63.3 & 3.3 \\
\hline 12 & Expressing my ideas & 30 & 1 & 5 & 3.33 & Frequency & 0 & 3 & 14 & 13 & 0 \\
\hline & $\begin{array}{l}\text { in writing is really } \\
\text { tough. }\end{array}$ & & & & & Percentage & 0 & 10.0 & 46.7 & 43.3 & 0 \\
\hline
\end{tabular}

Analyzing the experimental group students' responses as displayed in Table 5 showed a significant reduction in the students' anxiety level. According to the mean of the third statement $\mathrm{M}=1.56$, the students are no longer feel scared when writing under time limit. In addition, the mean of statement number six was $M=1.90$ which means that the students do not avoid writing tasks outside the class. Moreover, peer evaluation is no more a source of anxiety. A possible explanation for this significant reduction is that wiki provided a chance for collaboration among students and much time for writing was devoted. 
Table 5. Means, frequencies and percentages of the experimental group students' responses to the WAI statements after the intervention

\begin{tabular}{|c|c|c|c|c|c|c|c|c|c|c|c|}
\hline \multirow[b]{2}{*}{$\begin{array}{l}\text { Item } \\
\text { No. }\end{array}$} & \multirow[b]{2}{*}{ Statement } & \multirow[b]{2}{*}{$N$} & \multirow[b]{2}{*}{ Min } & \multirow[b]{2}{*}{$\operatorname{Max}$} & \multirow[b]{2}{*}{$M$} & \multicolumn{6}{|c|}{ Experimental Group } \\
\hline & & & & & & & 1 & 2 & 3 & 4 & 5 \\
\hline \multirow[t]{2}{*}{1} & \multirow{2}{*}{$\begin{array}{l}\text { I feel nervous when } \\
\text { I write. }\end{array}$} & \multirow[t]{2}{*}{30} & \multirow[t]{2}{*}{1} & \multirow[t]{2}{*}{5} & \multirow[t]{2}{*}{2.07} & Frequency & 0 & 28 & 2 & 0 & 0 \\
\hline & & & & & & Percentage & 0 & 93.3 & 6.7 & 0 & 0 \\
\hline \multirow[t]{2}{*}{2} & \multirow{2}{*}{$\begin{array}{ll}\text { Evaluating } & \text { my } \\
\text { writings is a real } \\
\text { embracement. }\end{array}$} & \multirow[t]{2}{*}{30} & \multirow[t]{2}{*}{1} & \multirow[t]{2}{*}{5} & \multirow[t]{2}{*}{2.60} & Frequency & 0 & 12 & 18 & 0 & 0 \\
\hline & & & & & & Percentage & 0 & 40.0 & 60.0 & 0 & 0 \\
\hline \multirow[t]{2}{*}{3} & \multirow{2}{*}{$\begin{array}{l}\text { I feel scared when I } \\
\text { write under time } \\
\text { limitation. }\end{array}$} & \multirow[t]{2}{*}{30} & \multirow[t]{2}{*}{1} & \multirow[t]{2}{*}{5} & \multirow[t]{2}{*}{1.80} & Frequency & 7 & 22 & 1 & 0 & 0 \\
\hline & & & & & & Percentage & 23.3 & 73.3 & 3.3 & 0 & 0 \\
\hline \multirow[t]{2}{*}{4} & \multirow{2}{*}{$\begin{array}{l}\text { I feel that } \\
\text { developing } \\
\text { well-organized } \\
\text { writings is beyond } \\
\text { my capabilities. }\end{array}$} & \multirow[t]{2}{*}{30} & \multirow[t]{2}{*}{1} & \multirow[t]{2}{*}{5} & 2.67 & Frequency & 0 & 10 & 20 & 0 & 0 \\
\hline & & & & & & Percentage & 0 & 33.3 & 66.7 & 0 & 0 \\
\hline 5 & I predict to do & 30 & 1 & 5 & 2.67 & Frequency & 1 & 8 & 21 & 0 & 0 \\
\hline & $\begin{array}{l}\text { poorly in writing } \\
\text { classes. }\end{array}$ & & & & & Percentage & 3.3 & 26.7 & 70.0 & 0 & 0 \\
\hline 6 & I avoid practicing & 30 & 1 & 5 & 1.90 & Frequency & 4 & 25 & 1 & 0 & 0 \\
\hline & $\begin{array}{l}\text { writing outside the } \\
\text { class. }\end{array}$ & & & & & Percentage & 13.3 & 83.3 & 3.3 & 0 & 0 \\
\hline 7 & Writing is a real & 30 & 1 & 5 & 2.37 & Frequency & 1 & 17 & 12 & 0 & 0 \\
\hline & waste of time. & & & & & Percentage & 3.3 & 56.7 & 40.0 & 0 & 0 \\
\hline 8 & I feel that my & 30 & 1 & 5 & 2.63 & Frequency & 0 & 14 & 13 & 3 & 0 \\
\hline & $\begin{array}{l}\text { colleagues' writings } \\
\text { are better than mine. }\end{array}$ & & & & & Percentage & 0 & 46.7 & 43.3 & 10.0 & 0 \\
\hline 9 & I do my best to & 30 & 1 & 5 & 2.60 & Frequency & 0 & 15 & 12 & 3 & 0 \\
\hline & $\begin{array}{l}\text { avoid written } \\
\text { assignments. }\end{array}$ & & & & & Percentage & 0 & 50.0 & 40.0 & 10.0 & 0 \\
\hline 10 & I do not like my & 30 & 1 & 5 & 1.83 & Frequency & 6 & 23 & 1 & 0 & 0 \\
\hline & $\begin{array}{l}\text { colleagues to read } \\
\text { my writings. }\end{array}$ & & & & & Percentage & 20.0 & 76.7 & 3.3 & 0 & 0 \\
\hline 11 & I expect to get low & 30 & 1 & 5 & 2.80 & Frequency & 1 & 5 & 23 & 1 & 0 \\
\hline & $\begin{array}{l}\text { score in writing } \\
\text { assignments. }\end{array}$ & & & & & Percentage & 3.3 & 16.7 & 76.7 & 3.3 & 0 \\
\hline 12 & Expressing my & 30 & 1 & 5 & 3.20 & Frequency & 0 & 4 & 16 & 10 & 0 \\
\hline & $\begin{array}{l}\text { ideas in writing is } \\
\text { really tough. }\end{array}$ & & & & & Percentage & 0 & 13.3 & 53.3 & 33.3 & 0 \\
\hline
\end{tabular}

\subsection{Discussion}

The findings of the present study can be interpreted in two aspects. First, wikis were found to be effective in developing the students' business writing skills as significant improvement was existed in the participants' performance in terms of form, organization, content, and mechanics. The positive effect of using wikis on students' business writing is attributed to the collaborative nature of wikis. Wikis provided the students with an ample chance to establish a solid ground for their collaboration. They supported each other as the goal was to 
produce quality writing. Wikis proved to be ideal for exchanging ideas, raising comments, improving peer feedback, and, finally, publishing final products.

Second, the findings of the study illustrate the positive effect of using wikis in reducing the writing anxiety of the students. The students were less scared to write and more willing to participate in writing activity. It seems that using wikis provide the students with a shelter to protect them from embarrassment and negative feeling towards writing. This finding is similar to the other studies that addressed the same issue (Alshumaimeri, 2011; Umar \& Rathakrishnan, 2012).

Students' familiarity with computers may be one of reasons that contributed to the success of wikis in reducing their anxiety level. Using a web-based tool in learning business writing was seen by the students as a helpful tool. It is assumed that using such technology fits the life-style of the twentieth first century university students. However, such social and cognitive aspects should be scientifically investigated. Eventually, the reciprocal relationship between writing and anxiety is assured throughout the present study. Thus, there is a real need to explore more teaching strategies that guarantee the development of writing performance in a free anxiety environment.

\subsection{Conclusion}

The present study sought to investigate the effect of using wikis on developing business writing skills and reducing writing anxiety. Based on the results, wikis were proved to be an effective tool for teaching business writing to EFL university students. In addition, positive effects were found on students' writing anxiety.

\subsection{Recommendations and Suggestions for Further Research}

In accordance with the findings of the present study, it is highly recommended to provide EFL instructors with a tailor-made trainging on using wikis in business writing instruction to guarantee the smooth development of their students' business writing skills and to reduce their writing anxiety too. This training should provide teachers with valid strategies to be implemented in the classroom to incorporae wikis successfully in writing classes.

The following topics are suggested as areas that need further investigation: the possible effect of using wikis on learners' motivation and attitudes, the potential factors that may lead to classroom anxiety in general and language learning in particular, other sources of anxiety that could appear with the excessive use of technology in classrooms, and, eventually, the replication of the present study using larger samples from different educational stages is recommended so as to determine to what extent the results of the present study can be generalized.

\section{References}

Abdel Latif, M. (2007). Factors accounting for Egyptian EFL university students' negative writing affect. Essex Graduate Student Papers in Language and Linguistics, 9, 57-82.

Ahmadi, S. \& Marandi, S. (2014). The effect of using the social tool of wikis on EFL learners' writing performance. Journal of Education and Practice, 5(37), 171-178.

Aljafen, B. (2013). Writing anxiety among EFL Saudi students in science colleges and departments at a Saudi university. Unpublished MA, Indiana University of Pennsylvania.

Alshumaimeri, Y. (2011). The effects of wikis on foreign language students writing performance. ProcediaSocial and Behavioral Sciences, 28,755-763. https://dx.doi.org/10.1016/j.sbspro.2011.11.139

Atay, D., \& Kurt, G. (2006). Prospective teachers and L2 writing anxiety. Asian EFL Journal, 8(4), 100-118.

Biesenbach-Lucas, S., Meloni, C., \& Weasenforth, D. (2001). E-mail and word processing in the ESL classroom: How the medium affects the message. Language Learning \& Technology, 5(1), 135-165.

Bobanović, M. (2016). Investigation of university students' EFL writing apprehension: A longitudinal study in Croatia. Review of Innovation and Competitiveness, 2(1), 5-18.

Bohns, Vanessa K. (2015, August 3). You're already more persuasive than you think. Harvard Business Review.

Boulous, M., Maramba, I., \& Wheeler, S. (2006). Wikis, blogs and podcasts: A new generation of web-based tools for virtual collaborative clinical practice and education. BMC Medical Education, 6(41), 1-8. https://dx.doi.org/10.1186/1472-6920-6-41

Choi, S. (2013). Language anxiety in second language writing: Is it really a stumbling block? Second Language Studies, 31(2), 1-42. 
Clark, D. (2005). Explorations into writing anxiety: Helping students overcome their fears and focus on learning. Paper presented at the ISSOTL Conference, Canada.

Condon, W., \& Kelly-Riley, D. (2004). Assessing and teaching what we value: The relationship between college-level writing and critical thinking abilities. Assessing Writing, 9(1), 56-75. https://dx.doi.org/10.1016/j.asw.2004.01.003

Coniam, D., \& Mak, B. (2008). Using wikis to enhance and develop writing skills among secondary school students in Hong Kong. System, 36(3), 437-455. https://dx.doi.org/10.1016/j.system.2008.02.004

Cunningham, W., \& Leuf, B. (2001). The wiki way: Quick collaboration on the web. Addison-Wesley: Longman Publishing Company, Inc.

Dwyer, J. (2005). Communication in business: Strategies and skills (3rd ed.). Pearson Education Australia: Frenchs Forest.

Ebersbach, A., Glaser, M., \& Heigl, R. (2006). Wiki: Web collaboration. New York: Springer.

Fritzsche, B. A., Youn, B. R. \& Hickson (2003). Individual differences in academic procrastination tendency and writing success. Personality and Individual Differences, 35(7), 1549-1557. https://dx.doi.org/10.1016/S0191-8869(02)00369-0

Gabrilovich, E., \& Markovitch, S. (2006). Overcoming the brittleness bottleneck using wikipedia: Enhancing text categorization with encyclopedic knowledge. Paper presented at the proceedings of the 21st National Conference on Artificial Intelligence.

Graham, S. (2008). Effective writing instruction for all students. Wisconsin: Renaissance Learning.

Hassan, B. (2001). The relationship of writing apprehension and self-esteem to the writing quality and quantity of EFL university students. Mansoura Faculty of Education Journal, 39, 1-36.

Huang, J. (2009). Factors affecting the assessment of ESL students' writing. International Journal of Applied Educational Studies, 5(1), 1-17.

Hussein, G., (2010). The attitudes of undergraduate students towards motivation and technology in a foreign language classroom. International Journal of Learning and Teaching, 2(2), 14-24.

Huwari, I. (2016). Student's strategies to reduce writing apprehension (A case study on Zarqa University). Mediterranean Journal of Social Sciences, 7(3), 283-290. https://dx.doi.org/10.5901/mjss.2016.v7n3s1p283

Jahin, J. H. (2007). An investigation into Saudi EFL major student teachers' perspectives on foreign language anxiety. Journal of Educational Research, 6(11), 1-79.

Jahin, J. H., \& Idrees, M. W. (2010). EFL major student teachers' writing proficiency and attitudes towards learning English. Um Al-Qura University Journal of Education and Psychology Sciences, 2(2), 9-73.

Kara, S. (2013). Writing anxiety: A case study on students' reasons for anxiety in writing classes. Anadoul Journal of Educational Sciences International, 3(1), 103-111.

Karakaya, I., \& Ulper, H. (2011). Developing a writing anxiety scale and examining writing anxiety based on various variables. Educational Sciences: Theory \& Practice, 11(2), 703-707.

Killeen, J. (2013, March 25). Poor writing skills lead to lost business and career paralysis. The Los Angeles Business Journal, An adveritising supplement, 28.

Kurk, G., \& Atay, D. (2007). Students' writing apprehension. Journal of Theory and Practice in Education, 3(1), $12-23$.

Lamb, A., \& Johnson, L. (2007). An information skills workout: Wikis and collaborative writing. Teacher Librarian, 34(5), 57-59.

Lamb, B. (2004). Wide open spaces: Wikis, ready or not. EDUCAUSE Review, 39(5), 36-48.

Langdon, S. (2005). Wiki \& blog: Using social communication tools for teaching writing. IATEFL CALL Review, 7, 38-40.

Li, M. (2012). Use of wikis in second/foreign language classes: A literature review. CALL-EL, 13(1), 17-35.

Lundin, R. (2008). Teaching with wikis: Towards a new worked pedagogy. Computers and Composition, 25(4), 432-448. https://dx.doi.org/10.1016/j.compcom.2008.06.001 
Magno, C. (2008). Reading strategy, amount of writing, metacognition, metamemory, and apprehension as predictors of English written proficiency. Asian EFL Journal, Professional Teaching Articles, 29(2), 16-48.

Nikitina, A. (2012). Improve your writing skills. Arina Nikitina \& Ventus Publishing Aps.

Olanezhad, M. (2015). A comparative study of writing anxiety among Iranian university students majoring English translation, teaching and literature. English Language Teaching, 8(3), 59-70. https://dx.doi.org/10.5539/elt.v8n3p59

Pae, J-K. (2007). Wiki-based English writing: Its effect on English writing proficiency and anxiety and Korean learners' perceptions. Multimedia-Assisted Language Learning, 10(1), 81-105.

Rankin-Brown, M. (2006). Addressing writing apprehension in adult English language learners. CATESOL State Conference. Pacific Union College, United States.

Stapa, S., \& Abul Majid, A. (2009). The use of first language in developing ideas in second language write. European Journal of Social Sciences, 7(4), 41-47.

Tsui, A. B. M. (1996). Reticence and anxiety in second language learning. In K. M. Bailey, \& D. Nunan (Eds.). Voices from the language classroom, 145-167. Cambridge: Cambridge University Press.

Tymson, C., Lazar, P., \& Lazar, R. (2008). The new Australian and New Zealand public relations manual (5th ed.). Manly NSW: Tymson Communications.

Umar, I., \& Rathakrishnan, M. (2012). The effects of online teachers' social role and learning style on students' essay writing performance and critical thinking in a wiki environment. Procedia Social and Behavioral Sciences, 46, 5730-5735. https://dx.doi.org/10.1016/j.sbspro.2012.06.506

Uzunboylu, H., Bicen, H., \& Cavus, N. (2011). The efficient virtual learning environment: A case study of web 2.0 tools and windows live spaces. Computers \& Education, 56(3), 720-726. https://dx.doi.org/10.1016/j.compedu.2010.10.014

Wilt, J., Oehlberg, K., \& Revelle, W. (2011). Anxiety in personality. Personality and Individual Differences, 50, 987-993. https://dx.doi.org/10.1016/j.paid.2010.11.014

Weimer, M. (2002). Learner-centered teaching. San Francisco, CA: Jossey-Bass.

Wen-Shuenn, W. (2006). The effect of blog peer review and teacher feedback on the revisions of EFL writers. Journal of Education and Foreign Languages and Literature, 3(3), 25-138.

West, J., \& West, M. (2009). Using wikis for online collaboration: The power of the read-write web. Jossey-Bass.

Wichadee, S. (2010). Using wikis to develop summary writing abilities of students in an EFL class. Journal of College Teaching \& Learning, 7 (12), 5-10.

Woods, D., \& Thoeny, P. (2011). Wikis for dummies. Indianapolis: Wiley Publishing, Inc.

Xiao, Y., \& Lucking, R. (2008). The impact of two types of peer assessment on students' performance and satisfaction within a wiki environment. Internet and Higher Education, 11, 186-193. https://dx.doi.org/10.1016/j.iheduc.2008.06.005

\section{Copyrights}

Copyright for this article is retained by the author(s), with first publication rights granted to the journal.

This is an open-access article distributed under the terms and conditions of the Creative Commons Attribution license (http://creativecommons.org/licenses/by/4.0/). 